\title{
STEVENS JOHNSON SYNDROME PADA PASIEN HIV
}

\author{
Bevi Dewi Citra ${ }^{1)}$, Raveinal' ${ }^{2}$ \\ ${ }^{1}$ PPDS Ilmu Penyakit Dalam Fakultas Kedokteran Universitas Andalas/RSUP M. Djamil Padang \\ email: bevidewicitra@gmail.com \\ ${ }^{2}$ Subbagian Alergi Imunologi Ilmu Penyakit Dalam Fakultas Kedokteran Universitas Andalas/RSUP M. Djamil \\ Padang
}

Submitted: 06-04-2020, Reviewer: 07-04-2020, Accepted: 09-04-2020

\begin{abstract}
Abstrak
Stevens Johnson Syndrome (SJS) merupakan salah satu bentuk reaksi hipersensitifitas obat yang memiliki morbiditas yang tinggi selain Toxic Epidermal Necrolysis (TEN). Penderita HIV merupakan salah satu populasi yang rentan terjadi SJS dikarenakan reaksi hipersensitivitas yang terjadi pada populasi ini bersifat multifaktorial, berhubungan dengan metabolisme obat, disregulasi sistem imun (hiperaktivasi imun, profil sitokin pasien, jumlah CD4), stres oksidatif, predisposisi genetik dan faktor-faktor virus itu sendiri. Telah dilaporkan kasus, wanita, 42 tahun yang merupakan penderita HIV stadium klinis 3 yang mengalami SJS. Diduga penyebabnya adalah salah satu obat anti retroviral (nevirapine) yang baru dikonsumsi oleh pasien selama 3 minggu, yang disertai dengan demam dan hepatitis drug induced. Pengobatan pada pasien ini adalah menghentikan kombinasi ARV yang dikonsumsi sebelumnya dan menggantinya dengan kombinasi yang lain. Selain itu, pasien mendapatkan terapi kortikosteroid, pengobatan suportif seperti cairan intra vena, nutrisi adekuat, antibiotik, anti jamur serta perawatan pada mata, oral, hidung dan kulit. Pasien menunjukkan perbaikan klinis dan perbaikan fungsi hati setelah satu minggu mendapatkan perawatan di rumah sakit
\end{abstract}

Kata Kunci: Stevens Johnson Syndrome, HIV, antiretroviral

\begin{abstract}
Stevens Johnson Syndrome (SJS) are form of drugs hypersensitivity reaction with high morbidity besides Toxic Epidermal Necrolysis (TEN). HIV-patients are one of the population with higher risk. Its due to, in this population had multifactorial aspects and related with drug metabolism, dysregulation of the immune systems (immune hyperactivation, patients cytokine profile and CD4 cell count), oxidative stress, genetic predisposition, and viral factors. A case of female, 42 years old, who had been known as HIV patients with clinical stage 3 had Stevens Johnson Syndrome. Allegedly, it caused by antiretroviral drugs (nevirapine), which she consumed for 3 weeks. Patient also has fever and hepatitis drug induced. For the the treatment, we stopped previous combination of antiretroviral drugs immediately and replaced by another combination. Furthermore, patient also had corticosteroid therapy and others supportive treatments, such as intra venous fluid, adequate nutrition, antibiotic, antifungal and also had eyelid, oral, nose and skin treatment. Patient showed clinical improvements and and improvement of liver function test after received treatments for one week in hospital
\end{abstract}

Keywords: Stevens Johnson Syndrome, HIV, antiretroviral 


\section{PENDAHULUAN}

Stevens Johnson Syndrome (SJS) adalah varian dari eritema multiforme yang merupakan reaksi hipersensitivitas kompleks imun yang bisa disebabkan oleh berbagai faktor, seperti infeksi, obat-obatan, dan keganasan ditandai oleh pengelupasan epidermis dan erosi pada membran mukosa. ${ }^{1}$ Eritema multiforme dibagi dalam tiga golongan, yakni Eritema multiforme minor, Eritema multiforme mayor atau Stevens johnson syndrome (SJS) dan Toxic Epidermal Necrolysis (TEN). ${ }^{2}$

Di Amerika Serikat, suatu penelitian menunjukkan insidensi eritema multiforme, SJS dan TEN 1,8 per sejuta pasien dengan rentang usia 20-64 tahun. Di Perancis, melalui survei nasional menginformasikan bahwa insiden SJS sebanyak 1,2 kasus per sejuta penduduk per tahun. ${ }^{3}$ Di Eropa dan Amerika Serikat, angka kejadian SJS diperkirakan 1-6 kasus per 1 juta pasien per tahun, lebih jarang pada pria dengan sex ratio $0,6 .^{4}$ Eritema mayor atau SJS, lebih sering mengenai pria muda dewasa. ${ }^{2}$ mortalitas SJS bervariasi dari $1 \%$ hingga $5 \% .^{3}$ Penelitian di salah satu RS di Afrika Selatan menunjukkan bahwa insiden terjadinya SJS/TEN terbanyak pada pasien HIV (Human Immunodeficiency Virus), dimana dari tahun 2004 hingga tahun 2006, insiden tersebut meningkat dari $40 \%$ menjadi $69 \%{ }^{6}$

Obat-obatan penyebab terbanyak kejadian SJS adalah antibiotik golongan sulfonamid (38\%) dan antiretroviral (ARV) seperti nevirapine $(20 \%)$ pada pasien HIV $(\text { tabel 1) })^{5,7}$

Tabel 1. Beberapa jenis obat yang dilaporkan sebagai penyebab $\mathrm{SJS}^{7}$

\begin{tabular}{l}
\hline Drug Classification \\
\hline Antibiotics \\
Anticonvulsants \\
Sulfonylureas \\
Diuretics \\
Analgesics \\
Antidepressants \\
Tyrosine Kinase Inhibitors \\
Xanthine Oxidase Inhibitors \\
Androgenic hormones \\
Antineoplastic drugs \\
Antiviral drugs \\
Combination drug(Aggrenox) \\
Immunosuppressant/modulators \\
Antihistamines \\
Angiotensin-converting enzyme inhibitors \\
Anti-osteoporotic agent \\
Contrast agent \\
Insecticide
\end{tabular}

SJS merupakan salah satu bentuk reaksi hipersensitivitas terhadap obat yang dikategorikan berat pada penderita HIV, hal ini dikaitkan dengan perubahan-perubahan respon imunologi yang terjadi sehingga penderita HIV merupakan salah satu populasi yang rentan terjadi SJS dibanding populasi lainnya dan yang perlu diperhatikan juga adalah bagaimana penatalaksanaanya. ${ }^{8}$

Respon imunologi terkait limfosit CD8 merupakan penyebab terbanyak dalam patogenesis SJS, tetapi faktor-faktor potensial yang terkait dengan obat sebagai penyebab SJS juga tidak dapat disingkirkan, seperti struktur kimia, kondisi pasien, misalnya pasien HIV dan jumlah CD4, ras etnik, usia dan jenis kelamin. ${ }^{5}$

\section{PATOGENESIS}

Patogenesis SJS sampai saat ini masih belum didefinisikan pasti (gambar 1). ${ }^{9}$ Beberapa mekanisme terjadinya SJS di antaranya: ${ }^{10}$

1.Cell-mediated cytotoxic reaction terhadap keratinosit, yang mengakibatkan apoptosis masif melalui perforin-granzyme $B$ atau Fas-FasL

2.Teori reaksi idiosinkrasi dan immune complex mediated hypersensitivity

3.Teori lainnya adalah slow acetylation (gangguan metabolisme obat) sehingga 
terjadi peningkatan produksi metabolit reaktif yang bersifat toksik atau dapat memicu respons imun sekunder

4.Teori kerentanan genetik, yang mengatakan adanya asosiasi kuat antara HLA-B75 (alel B*1502) dari HLA-B dan SJS akibat karbamazepin dan fenitoin,dan antara HLA-B58 (alel B*5801) dan SJS akibat alopurinol pada orang Asia

\section{GEJALA KLINIS}

Gejala prodromal SJS dapat berupa demam tinggi, astenia, sakit otot, diare, muntah, atralgia dan faringitis yang mendahului keterlibatan 2 atau lebih mukosa dalam beberapa hari. Kulit mulai terlibat dengan cepat. $^{2}$

Komplikasi dari SJS, selain dari nyeri yang hebat, termasuk didalamnya bisa terjadi ulserasi kornea, uveitis anterior, panophthalmitis dan kebutaan. Keterlibatan gastrointestinal bisa menyebabkan striktur esofagus. Keterlibatan saluran kemih bisa menyebabkan renal tubular necrosis dan gagal ginjal, dan juga menyebabkan luka pada penis dan stenosis vagina. Keterlibatan paru bisa menyebabkan peluruhan mukosa tracheo-bronchial dan gagal napas. Adanya rekurensi infeksi, sepsis, bekas luka dan deformitas kosmetik juga merupakan bentuk komplikasi lain dari SJS. ${ }^{3}$

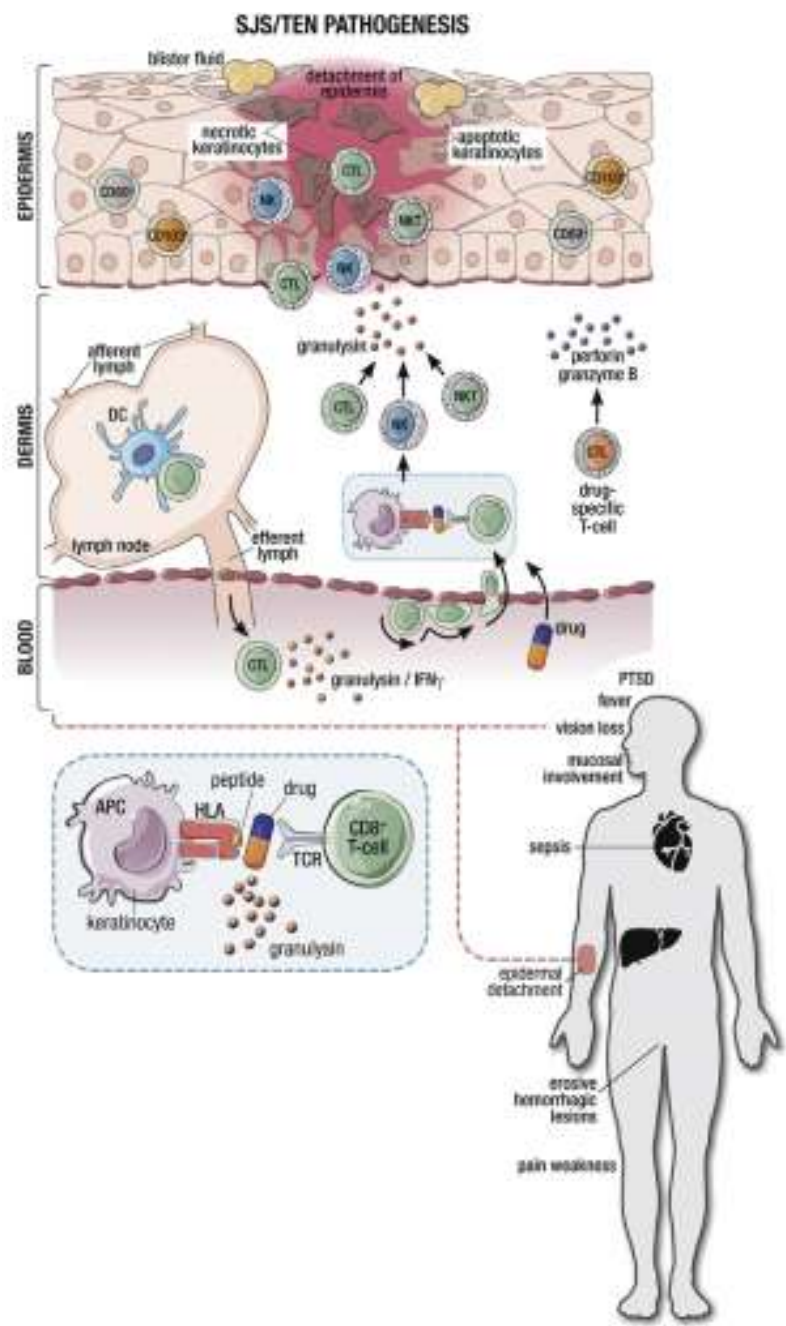

Gambar 1. Patogenesis $\mathrm{SJS}^{9}$ DIAGNOSIS

Diagnosis eritema multiforme bisa tercampur dengan SJS, karena keduanya menunjukkan adanya rash dan erosi pada mukosa. ${ }^{10}$ Di antara ketiga subgrup EM ada tumpang tindih, namun ada beberapa ciri spesifik yang dapat digunakan untuk membedakannya satu dari yang lain. SJS dengan TEN hanya berbeda dalam luas nekrolisis dan prognosis dan tidak berbeda dalam kriteria lainnya (tabel 2) $)^{2,7,11}$ Adapun prognosis SJS/TEN dapat ditentukan melalui kriteria SCORTEN yang diperkenalkan oleh Bastuji-Garin et al tahun 2000, yakni beberapa faktor risiko yang mempengaruhi mortalitas pasien: ${ }^{12}$ 
- Usia $>40$ tahun

- Keganasan

- Total Body Surface Area (BSA) yang terkena $>10 \%$

- Frekuensi nadi $>120 x /$ menit

- Blood Urea Nitrogen (BUN) > 28 mg per dl

- glukosa serum $>250 \mathrm{mg}$ per dl

- bicarbonate serum $<20 \mathrm{mEq} / \mathrm{liter}$

Tabel 2. Perbedaan Manifestasi Klinis SJS, TEN dan SJS-TEN overlap $^{7}$

\begin{tabular}{|c|c|c|c|}
\hline Clinical entity & 5.S & SJS-TEN overlap & TEN \\
\hline \multirow[t]{2}{*}{ Prinary Lesions } & Dusky red lesions & Dusky red lesions & $\begin{array}{l}\text { Poorly delineated } \\
\text { erythematcus plaques }\end{array}$ \\
\hline & Fat abypical targets & Flat atypitai targets & $\begin{array}{c}\text { Epidermal detachment } \\
\text { Dusky red lesions } \\
\text { Flat atypical targets }\end{array}$ \\
\hline \multirow[t]{2}{*}{ Distribution } & isclated lesions & Isclated lesions & Isolated lesions (rare) \\
\hline & $\begin{array}{l}\text { Confluente }(+) \text { on } \\
\text { face and trunk }\end{array}$ & $\begin{array}{l}\text { Confluence }(++) \text { on } \\
\text { face and runk }\end{array}$ & $\begin{array}{c}\text { Confuence }(t+i+\} \text { on face } \\
\text { tunk, and e'se where }\end{array}$ \\
\hline $\begin{array}{l}\text { Muscosai } \\
\text { involvement }\end{array}$ & Yes & Yes & Yes \\
\hline Systemic symptoms & Usualy & Ahways & A/way5 \\
\hline $\begin{array}{l}\text { Delachment (sibody } \\
\text { surface area) }\end{array}$ & $<10$ & $10-30$ & $>30$ \\
\hline
\end{tabular}

\section{ILUSTRASI KASUS}

Telah dirawat seorang pasien perempuan 42 tahun di bangsal penyakit dalam RSUP M.Djamil Padang sejak tanggal 27 Juni 2015 dengan keluhan utama bibir makin melepuh sejak 3 hari sebelum masuk rumah sakit. awalnya keluhan mulai dirasakan sejak 1 minggu sebelumnya, diawali dengan bengkak kemerahan kemudian mulai melepuh dan timbul keropeng. Pasien sebelumnya baru dikenal menderita HIV sejak 3 minggu yang lalu, dan telah mendapatkan obat anti virus dan mengkonsumsinya secara teratur, yakni neviral (nevirapine) dan lamivudine $150 \mathrm{mg}$ - zidovudine $300 \mathrm{mg}$. Pasien mengeluhkan demam, hilang timbul, tidak terlalu tinggi, tidak disertai menggigil, sering berkeringat banyak. Terdapat penurunan nafsu makan, mual tetapi tidak ada muntah.

Kulit pasien mulai melepuh sejak 10 sebelum masuk rumah sakit. Awalnya timbul bercak-bercak kemerahan di seluruh tubuh kemudian melepuh dan mengelupas dan terasa nyeri. Mata pasien kemerahan sejak 10 hari yang lalu, berair dan mulai timbul keropeng di sudut-sudut mata tetapi penglihatan tidak kabur.

Pasien juga mengeluhkan nyeri menelan sejak 10 hari sebelum masuk rumah sakit, terdapat keropeng di dalam rongga hidung tetapi tidak ada gangguan penciuman, pasien merasakan kesulitan untuk menarik napas melalui hidung. Pasien sulit membuka mulut dan nyeri saat BAK. Keluhan sesak nafas, BAB encer, penurunan berat badan tidak ada.

Riwayat menkonsumsi OAT selama 6 bulan disangkal, riwayat alergi obat atau makanan tidak ada, riwayat sakit gula tidak ada, riwayat tekanan darah tinggi dan sakit jantung tidak ada. Riwayat menderita keganasan dan sakit kuning tidak ada.

Suami pasien sebelumnya menderita diare kronik dan batuk lama, kemudian mengalami penurunan kesadaran. Suami pasien meninggal 1 bulan yang lalu dan dikatakan menderita HIV AIDS. Pasien dan anak-anak diminta memeriksakan diri dengan hasil pasien menderita HIV sedangkan anak-anak pasien hasilnya negatif. Pasien tidak memiliki keluarga yang menderita penyakit kulit seperti ini sebelumnya.

Pasien adalah ibu rumah tangga, telah mempunyai 3 orang anak, riwayat seks bebas disangkal, riwayat penggunaan jarum suntik bersama disangkal dan tidak memiliki tato.

Saat awal masuk, keadaan umum pasien tampak sakit sedang, kesadaran komposmentis dengan tekanan darah : $110 / 70 \mathrm{mmHg}$, frekuensi nadi $98 \mathrm{x} / \mathrm{menit}$, teratur, pengisian cukup, frekuensi nafas 20 $\mathrm{x} /$ menit dan temperatur $38^{\circ} \mathrm{C}$. Body Mass Index pasien $21,33 \mathrm{~kg} / \mathrm{m}^{2}$ (normoweight), tidak terdapat ikterik dan anemis. Tidak terdapat pembesaran kelenjar getah bening. Pada pemeriksaan fisik mata terdapat 
konjungtiva hiperemis dan krusta. Telinga dalam batas normal. Krusta juga ditemukan pada lubang hidung dan bibir. Pada pemeriksaan paru dan jantung dalam batas normal. Pada pemeriksaan abdomen ditemukan hepatomegali.

Status dermatologis pasien terdapat effloresensi berupa makula eritem dan erosi, dari berbentuk bulat hingga tidak tegas, berukuran miliar-plakat yang berlokasi di wajah, leher, dada, punggung, kedua lengan atas, telapak tangan dan telapak kaki (gambar 2 dan 3). Status venerologi tidak ditemukan kelainan.
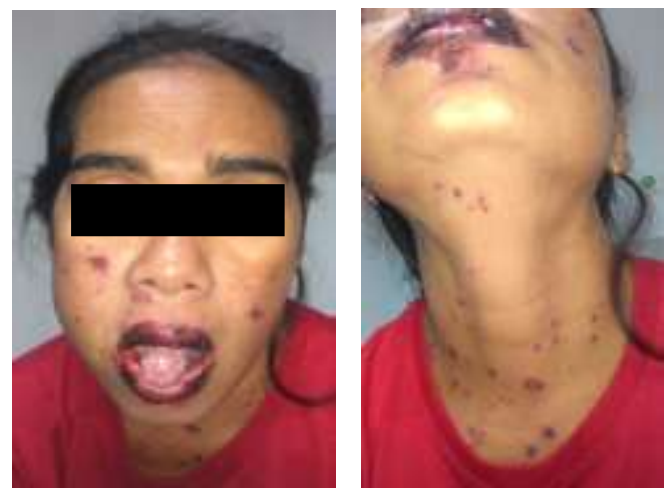

Gambar 2. Gambaran makula eritema pada kulit wajah dan leher, blepharokonjungtivitis serta krusta pada bibir.

Pemeriksaan penunjang ditemukan $\mathrm{Hb}$ $11 \mathrm{~g} / \mathrm{dl}$, Ht $31 \%$, leukosit $3.900 / \mathrm{mm}^{3}$, trombosit 311.000/ $\mathrm{mm}^{3}$, LED $70 \mathrm{~mm} / \mathrm{jam}$ dan hitung jenis leukosit 0/0/1/70/19/10. Dari pemeriksaan gambaran darah tepi: eritrosit anisositosis normokrom, leukosit jumlah berkurang, distribusi dan morfologi normal dan trombosit jumlah cukup, morfologi normal. Pada pemeriksaan kimia klinik diperoleh gula darah sewaktu 140 $\mathrm{mg} / \mathrm{dl}$, faal ginjal dalam batas normal terdapat gangguan faal hati yakni SGOT 208 $\mathrm{u} / \mathrm{l}$ dan SGPT $770 \mathrm{u} / \mathrm{l}$, Bilirubin Total 1,8 $\mathrm{mg} / \mathrm{dl}$, Bilirubin direk 1,2 mg/dl, Bilirubin indirek 0,6 mg/dl, albumin dan globulin dalam batas normal. Terdapat peningkatan alkali fosfatase, yaitu $221 \mathrm{u} / \mathrm{l}$, dan peningkatan Gamma GT, yaitu sebesar 423 $\mathrm{u} / \mathrm{l}$, dari pemeriksaan $\mathrm{HBsAg}$ didapatkan non reaktif, begitu juga dengan Anti HCV yang negatif dan IgM anti HAV yang negatif,. Hasil pemeriksaan CD4 pasien 369 $\mathrm{sel} / \mathrm{mm}^{3}$ dan IgE total $332 \mathrm{IU} / \mathrm{mL}$ (Normal; < $87 \mathrm{IU} / \mathrm{mL})$. Pemeriksaan urinalisa dan feses rutin masih dalam batas normal. Hasil pemeriksaan rontgen thorax terdapat kesan bronchopneumonia, tetapi tidak sesuai dengan klinis dan hasil pemeriksaan fisik.
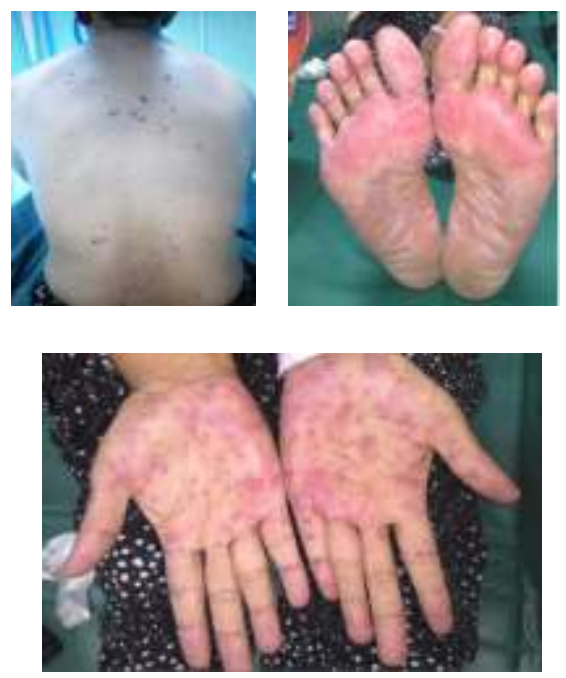

Gambar 3. Gambaran makula eritema plakat pada bagian punggung, telapak tangan dan kaki pasien

Pasien diberikan terapi Inj methylprednisolon 3 x $62,5 \mathrm{mg}$ selama 3 hari kemudian ditappering off, fluconazole infus 1 x $200 \mathrm{mg}$, Osteocal tablet 1 x 1000 $\mathrm{mg}$, Asam folat 1 x $5 \mathrm{mg}$, Nistatin drop 4 x 1 cc, Paracetamol tablet 3 x $500 \mathrm{mg}$, Gentamicin 2 x $80 \mathrm{mg}$, Cendo lyters eye drop tiap jam ODS, Levofloxacin eye drop 6 x 1 ODS dan salep Hydrocortison 2,5\% 2 x sehari pada bercak-bercak merah dikulit. Kombinasi ARV yang lama (nevirapine, lamivudine dan zidovudine) distop, kemudian selanjutnya diganti dengan kombinasi ARV tenofovir 1 x 300 mg, hiviral 2 x $150 \mathrm{mg}$ dan efavirenz 1 x 600 mg. Pada pasien juga dilakukan eyelid hygiene ODS, dan tantum verde $3 \times 1$ cup serta diberikan drip Stronger Neo 
Minophagen $C$ (SNMC) selama 5 hari. Pasien menunjukkan respon pengobatan setelah mendapatkan satu minggu perawatan di rumah sakit (gambar 4 dan 5).

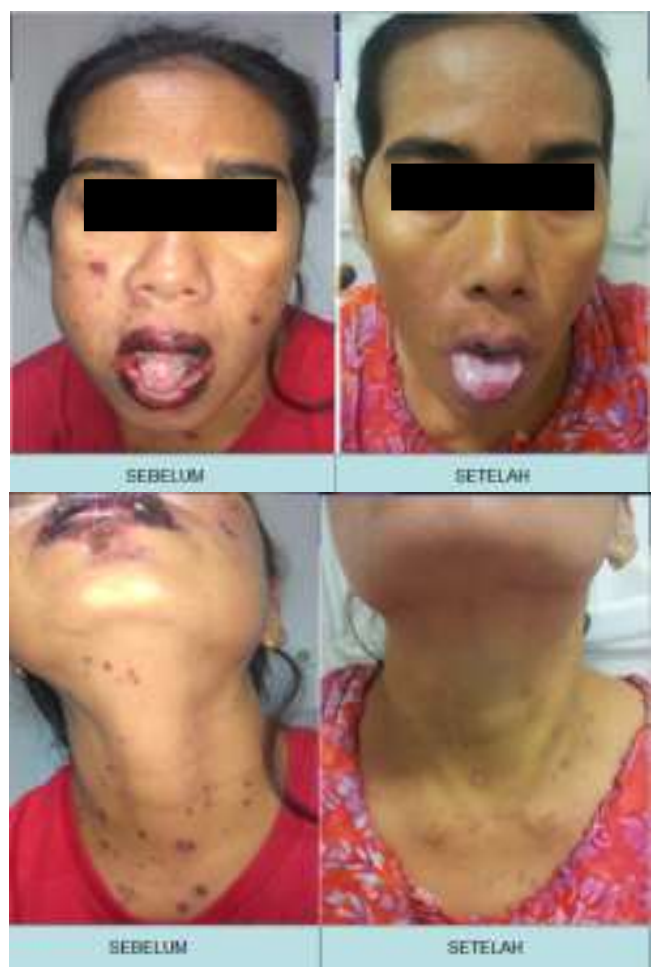

Gambar 4. Perbaikan klinis pada wajah, mata bibir dan kulit leher

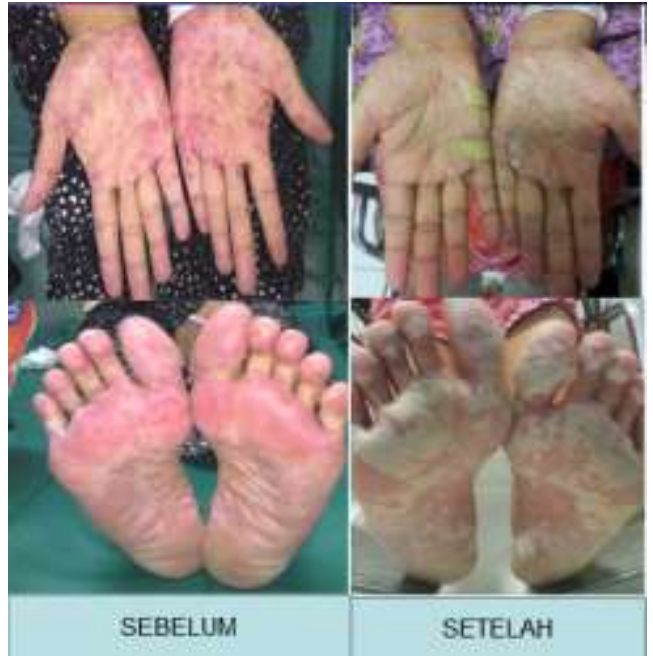

Gambar 5. Perubahan pada permukaan telapak tangan dan kaki

\section{DISKUSI}

Telah dirawat seorang pasien perempuan 42 tahun di bangsal penyakit dalam RSUP M.Djamil Padang sejak tanggal 27 Juni 2015 dengan diagnosis akhir: Stevens Johnson Syndrome ec Antiretroviral (nevirapine), Hepatitis Drug Induced ec Antiretroviral, HIV AIDS stadium klinis 3 dalam terapi, blefarokonjungtivitis ec SJS, dan oral mucositis ec SJS.

Stevens Johnson Syndrome merupakan penyakit yang disebabkan oleh reaksi hipersensitif (alergi) terhadap obat. Infeksi HIV, penyakit jaringan ikat dan kanker merupakan faktor risiko penyakit ini. ${ }^{10}$ Pasien ini sebelumnya mengkonsumsi ARV jenis neviral (nevirapine) dan lamivudine $150 \mathrm{mg}$ - zidovudine $300 \mathrm{mg}$ selama 3 minggu. Adanya SJS pada pasien ini diduga akibat hipersensitivitas terhadap obat antiretroviral.

Patofisiologi terjadinya hipersensitivitas obat pada pasien HIV bersifat multifaktorial dan berhubungan dengan metabolisme obat, disregulasi sistem imun (hiperaktivasi imun, profil sitokin pasien), stres oksidatif, predisposisi genetik dan faktor-faktor virus itu sendiri. Kejadian Cutaneus Adverse Drug Reaction (CADR), salah-satunya SJS, jumlahnya meningkat sesuai dengan sistem imun yang memburuk yang tampak pada jumlah $T$-cell CD4 yang menurun. Faktor-faktor lain yang berperan pada peningkatan frekuensi SJS adalah meningkatnya usia, adanya penyakit kulit lain, adanya bukti keaktifan (baik akut atau reaktivasi) dari virus Epstein-Barr daninfeksi sitomegalovirus. Beberapa studi menunjukkan bahwa peningkatan level Immunoglobulin $\mathrm{E}$ pada pasien HIV bisa menyebabkan progresivitas CADR (termasuk SJS) meningkat dan semakin menurunkan jumlah CD4. Pasien HIV memiliki proporsi interferon- $\gamma$-producing (Tipe Th1) klon CD4 yang menurun dan peningkatan proporsi dan IL-4-producing (Tipe Th2) klon CD4. Studi Immunofluoresen dan immunochemistry dari 
biopsi pasien HIV dengan CADR menunjukkan bahwa infiltrasi dari aktivasi limfosit CD8 dan produksi sitokin epidermis. $^{8}$

Pada pasien ini pemberian nevirapine dihentikan, dan setelahnya diberikan terapi ARV yang baru sebagai pengganti, yaitu: tenofovir $1 \times 1$, hiviral $2 \times 1$, efavirenz $1 \times 1$. Hiviral mengandung lamivudine, sama dengan jenis obat yang diberikan sebelumnya, tetapi setelah pasien mengkonsumsi ARV pengganti, pasien tidak menunjukan perburukan kondisi, baik secara klinis maupun laboratorium. Sehingga kemungkinan besar SJS disebabkan oleh nevirapine. SJS/TEN telah dilaporkan terjadi pada pasien HIV yang diberikan terapi nevirapine sebanyak $0,3-0,37 \%$. Nevirapine juga menyebabkan terjadinya hipersensitivitas dan hepatoksisitas pada pasien HIV. ${ }^{8}$ Berdasarkan data penelitian lainnya penyebab terbanyak SJS adalah jenis obat antibiotik golongan sulfonamid (38\%) dan nevirapine $(20 \%) .^{5}$ Sebuah penelitian telah dilaporkan bahwa SJS/TEN timbul sekitar 4-6 minggu setelah terapi nevirapine dan berdasarkan jenis kelamin nevirapine lebih sering menyebabkan reaksi hipersensitivitas pada wanita dengan jumlah CD4 >250 sel/mm3.,13 Tindakan menghentikan pemberian nevirapine pada pasien ini sesuai dengan kepustakaan, dimana pemberian nevirapine sebaiknya dihentikan jika nevirapine dicurigai sebagai penyebab terjadinya rash dengan disertai gejala konstitusional seperti demam, gangguan faal hati yang signifikan, blistering, lesi oral, konjungtivitis, edema wajah, arthralgia, malaise dan disfungsi organ. ${ }^{8}$

SJS merupakan penyakit akut, selflimited disease dengan tingkat morbiditas tinggi dan potensial mengancam jiwa. ${ }^{1}$ Untuk selanjutnya pada pasien tetap harus di follow-up klinis dan fungsi ginjal dan hati setelah mengkonsumsi ARV. Jika dalam perjalanan penyakit pasien dalam terapi ARV mengalami gejala intoksikasi dan intoleransi, maka ARV yang dikonsumsi sebelumnya disubstitusi atau dihentikan. Berdasarkan Pedoman Nasional Tatalaksana klinis infeksi HIV dengan Terapi Antiretroviral Pada Orang Dewasa yang dikeluarkan oleh Kementerian Kesehatan Republik Indonesia, substitusi individual dari obat ARV karena toksisitas atau intoleransi harus diambil dari kelas ARV yang sama, dan pada pasien ini nevirapine diganti dengan efavirenz. Bila toksisitas yang mengancam jiwa muncul, semua obat ARV harus dihentikan segera hingga secara klinis sembuh. Pada saat pasien sembuh maka dimulai dengan paduan terapi ARV yang lain. ${ }^{13}$

Diagnosis Hepatitis Drug Induced ec ARV pada pasien ini ditegakkan berdasarkan anamnesis, pemeriksaan fisik dan pemeriksaan penunjang. Pada anamnesis didapatkan keluhan pasien berupa mual sejak 2 minggu sebelum masuk rumah sakit, pasien mengkonsumsi ARV sejak 3 minggu sebelum masuk rumah sakit. Pada pemeriksaan laboratorium didapatkan peningkatan SGOT/SGPT 770/208 u/l, Bilirubin total 1,8 mg/dl, Bilirubin Direk 1,2 $\mathrm{mg} / \mathrm{dl}$, Bilirubin Indirek 0,6 mg/dl, Gama GT 423 u/l dan alkali Fosfatase 221 u/l. Pada tahun 2001, American Association for the Study of Liver Diseases (AASLD) menetapkan bahwa peningkatan kadar alanin aminotransferase (ALT) lebih dari tiga kali batas atas normal (BAN) dan peningkatan bilirubin total lebih dari dua kali BAN dapat digunakan sebagai kriteria untuk menentukan ada tidaknya kelainan signifikan pada parameter laboratorik hati. Peningkatan kadar enzim hati alanin transaminase (ALT), aspartat aminotransferase (AST) dan alkali fosfatase (ALP) dianggap sebagai indikator jejas hati, sedangkan peningkatan bilirubin total dan terkonjugasi merupakan parameter untuk 
menilai fungsi hati secara keseluruhan. Penilaian pola jejas hati sangat penting karena obat-obat tertentu cenderung menyebabkan jejas dengan pola khas pula. Penyebab abnormalitas fungsi hati pada pasien ini, diduga karena obat anti retroviral yang dikonsumsi pasien selama 3 minggu, tetapi tidak menutup kemungkinan bisa disebabkan oleh infeksi virus HIV, virus hepatitis, malignansi atau infeksi sistemik. Berdasarkan kepustakaan, abnormalitas fungsi hati biasanya disebabkan oleh infeksi HIV, virus hepatitis, keganasan, infeksi sistemik dan drug-induced hepatotoxicity. ${ }^{24}$ Bjornsson (2006), obat yang sering menyebabkan cedera hati fatal, salah satunya adalah obat anti HIV, seperti nevirapine dan zidovudine $(16,8 \%){ }^{15}$ Jejas hati hepatoselular (atau sitolitik) menyebabkan peningkatan kadar ALT dan AST serum yang bermakna, biasanya mendahului peningkatan bilirubin total, disertai sedikit peningkatan ALP. Menurut beberapa penelitian, pemakaian ARV dapat mengakibatkan SJS/TEN dan anicteric hepatitis $(<5 \%)$. Bercak kemerahan muncul pada pasien yang mendapat terapi nevirapine selama 2-8 minggu, angka kejadian tinggi pada wanita dan akan berbanding lurus dengan peningkatan CD4. ${ }^{16}$

Tatalaksana pada pasien ini, selain menghentikan obat tersangka, terapi suportif seperti pemberian cairan intravena, nutrisi adekuat, perawatan mata, hidung dan mulut, pasien juga diberikan kortikosteroid dan menunjukkan perbaikan klinis yang signifikan. Pemberian kortikosteroid sendiri masih menjadi perdebatan para ahli mengenai keuntungan dan kerugiannya pada tatalaksana SJS, tetapi pemberian kortikosteroid dengan dosis anti inflamasi dan diberikan dalam waktu singkat pada pasien ini menunjukkan perbaikan klinis yang nyata. ${ }^{6}$ Penelitian observasional meta analisis dari Zimmerman et al (2017) menunjukkan bahwa di antara pemberian terapi immonomodulating pada SJS/TEN (termasuk Intra Venous Immunoglobulin/IVIG, kortikosteroid pulsed dose dan siklosporin) menunjukkan bahwa kortikosteroid dihubungkan dengan keuntungan survival yang lebih baik sedangkan IVIG tidak menunjukkan keuntungan. ${ }^{17}$

Prognosis pasien ini baik. Berdasarkan skor yang diperoleh dari kriteria SCORTEN, pasien ini hanya memiliki mortalitas sebanyak 3\%.,12

\section{SIMPULAN}

Populasi penderita HIV sangat rentan terhadap kejadian Stevens Johnson Syndrome, baik dikarenakan perubahan respon imunologi, kondisi klinis, kaitannya dengan jumlah CD4 serta riwayat obatobatan yang dikonsumsi sebagai antivirus atau penanganan koinfeksi. Oleh karena itu, pemantauan terhadap perubahan klinis dan laboratorium terhadap pengobatan yang diterima oleh penderita HIV dipandang perlu dilakukan secara berkala.

\section{DAFTAR PUSTAKA}

1. Vijaykumar Lakshman Lamani, Basavaraj C Kotinatot, Aruna Bhushan. Nevirapine induced Stevens-Johnson syndrome. International Journal of Current Research and Academic Revie. 2015, Volume 3(2): 156-8

2. Karnen Garna Baratawidjaja, Iris Rengganis. Reaksi Obat Dengan Lepuh dalam Alergi Dasar. Jakarta: Interna Publishing. 2009; 560-79

3. Syed Ahmad Ali Gardezi et al. A clinicoetiological study of StevensJohnson syndrome and toxic epidermal necrolysis. Journal of Pakistan Association of Dermatologists. 2013; volume 23(1) :5-13.

4. Allanore LV, Roujeau JC. Epidermal necrolysis (Stevens-Johnson syndrome 
and toxic epidermal necrolysis). In: Wolff K, Goldsmith LA, Katz SI, Gilchrest BA, Paller AS, Leff el DJ, editors. Fittzpatrick's Dermatology in General Medicine. 7th ed. New York: McGraw-Hill Companies Inc; 2008. pp. 347-54

5. Z Zingela, A Bronkhorst, W M Qwesha, B P Magigaba. Fatal nevirapine-induced Stevens-Johnson syndrome with HIVassociated mania, case report. S Afr J HIV Med Volume 15(2), 2014 :65-66

6. Rannakoe Lehloenya. Management of Stevens Johnson Syndrome and Toxic Epidermal Necrolysis. Current Allergy \& Clinical Immunology, August 2007 Vol 20, No. 3; $124-8$

7. Fakoya A, Omenyi P, Anthony $\mathrm{P}$ et al. Stevens - Johnson Syndrome and Toxic Epidermal Necrolysis; Extensive Review of Reports of Drug-Induced Etiologies, and Possible Therapeutic Modalities. Macedonian Journal of Medical Sciences. 2018 Apr 15; 6(4):730-738.

8. Evy Yunihastuti, Alvina Widhani, Teguh Harjono Karjadi. Asia Pac Allergy 2014;4:54-67

9. White K, Riichiro Abe, Ardern-Jones M et al. SJS/TEN 2017: Building Multidisciplinary Networks to Drive Science and Translation. J Allergy Clin Immunol Pract Volume 6, No.1. 2018;39-69

10. Hari Darmawan. Sindrom StevensJohnson Diduga Akibat Siprofloksasin, case report. Cermin Dunia Kedokteran, CDK-217 volume 41 (6). 2014. 432-5

11. HHF Ho. Diagnosis and Management of Stevens-Johnson Syndrome and Toxic Epidermal Necrolysis. The Hongkong Medical Diary. Volume 13 (10). 2008. 17-20

12. Schneider J, Cohen P. Stevens-Johnson Syndrome and Toxic Epidermal Necrolysis: A Concise Review with a
Comprehensive Summary of Therapeutic Interventions Emphasizing Supportive Measures. Adv Ther (2017) 34:1235-1244

13. Kementerian kesehatan Republik Indonesia. Pedoman Nasional Tatalaksana klinis infeksi HIV dengan Terapi Antiretroviral Pada Orang Dewasa. Direktorat Jendral Pengendalian Penyakit dan Penyehatan Lingkungan. 2011

14. Kantorinis N, Dieterich D. Hepatotoxicity of Antiretroviral Therapy. AIDS Rev, Volume 5, 2003; 36-43

15. Suharjo Cahyono. Penyakit hati Akibat Obat dalam tatalaksana klinis di Bidang Gastro dan Hepatologi. Jakarta; Sagung Seto. 338-345

16. Marfatia, Smita M. Adverse Drug reactions (ADR due To Anti Retroviral (ARV) : issues and Challenges. Indian $\mathrm{J}$ Sex transm Dis, Volume 2005; $26(1,2)$. 2005. ; 40-49

17. Zimmermann S, Sekula P, Venhoff M, Motschall E, Knaus J, Schumacher M, et al. Systemic immunomodulating therapies for Stevens-Johnson syndrome and toxic epidermal necrolysis: a systematic review and meta-analysis. JAMA Dermatol 2017;153:514-22. 